Article

\title{
Conventual Writing and Context: The Case of Port-Royal
}

\author{
John J. Conley
}

Philosophy and Theology Departments, Loyola University Maryland, Baltimore, MD 21210, USA;

jconley1@loyola.edu

Received: 11 December 2017; Accepted: 26 February 2018; Published: 1 March 2018

\begin{abstract}
Many of the spiritual texts produced in the early modern period were written by nuns. To teach these texts adequately, it is not sufficient to study the work itself or the biography of the author. Effective exegesis of the texts requires detailed attention to the conventual culture in which these works were written, since this culture is foreign to the vast majority of contemporary students and readers. This contextual analysis operates on three levels. The first level introduces the students to the general nature of the convent and the life of a nun: the evangelical vows, the rule/constitution of the order, and the different types of religious orders. The second level focuses on the specific culture of the convent where the texts were composed. This involves analysis of the convent's particular spirituality, apostolate, literary genres of communication, and relationship to broader ecclesiastical and political movements of the times. The third level studies the gendered nature of the nuns' writings. This contextualist-cultural method of teaching écriture couventuelle is illustrated through analysis of the writings of the prolific Port-Royal abbess, Angélique de Saint-Jean Arnauld d'Andilly.
\end{abstract}

Keywords: Augustinian; Benedictine; Cistercian; convent; gender; Jansenism; Port-Royal; pedagogy; resistance; vows

\section{Introduction}

During the past twenty years, much of my research has been devoted to the translation of and commentary on philosophical and theological works written by women in early modern France. I have had the occasion to teach these works in graduate seminars and undergraduate honors seminars and to present papers on these works to professional and general audiences. As my research developed, I began to focus on texts written by nuns at the Jansenist convent of Port-Royal, especially Jacqueline Pascal (1625-1661) ${ }^{1}$ and three abbesses from the Arnauld family: Angélique Arnauld (1591-1661), Agnès Arnauld (1593-1671), and Angélique de Saint-Jean Arnauld d'Andilly (1624-1684). ${ }^{2}$

I soon learned that teaching and lecturing on these works posed steep pedagogical challenges. Even the clearest translation required some explanation of the more obscure French and Latin terms in works composed four centuries ago. The spirituality of the authors cannot be grasped independently of the theological controversies in which they were embroiled. The querelle de la grâce and the battle over frequent reception of the sacraments must be addressed if the texts are to be intelligible to the contemporary reader. The "crisis of the signature," which presented the occasion for many of these authors to defend the rights of conscience, is opaque unless the reader understands the nature of the church's condemnation of Jansenius's book Augustinus and the Gallican power of the French throne to intervene in theological quarrels and to punish the recalcitrant.

1 See (Pascal 2003).

2 See (Conley 2009; d'Andilly 2015). 
I also realized that the fact that these authors were nuns posed special problems for contemporary students. Many contemporary readers, even practicing Catholics, have had no personal experience of being taught by nuns and being familiar with the world of the convent. The monastic vows, liturgical prayer and personal meditation, and the constitutions of religious orders are an enigma to them. Many conventual literary genres, such as abbatial conferences and letters of spiritual direction, appear impenetrably arcane. The effective teaching of such spiritual works requires a study of the conventual culture in which these texts emerged and to which they frequently refer.

\section{Pedagogical Challenge of the Convent}

The first level of contextualization is essentialist in nature. This introduces students to the world of the convent and to the question: What or who is a nun?

Contemporary students often require basic information on the nature of the life lived by women in Catholic religious orders. The church's code of canon law succinctly summarizes the essentials of this vocation, albeit in a dry legalistic fashion. ${ }^{3}$

One of the essential features of life in a religious order is a commitment to the three vows of chastity, poverty, and obedience. The vow of chastity entails the renunciation of the right to marry and a commitment to lead a celibate life. The vow of poverty involves the renunciation of all private property and a commitment to live by the economic resources of one's religious community. The vow of obedience is primarily tied to mission. One's religious superior (often an abbess or prioress in a women's order) assigns subjects to particular offices or tasks.

It is unsurprising that such a way of life, so foreign to middle-class American norms, baffles most contemporary students. Misunderstanding is frequent. The vow of obedience does not dispense anyone from the generic demands of the moral order. A superior may not order a subject to commit perjury or to rob a drugstore in order to increase the community's funds. The vow of poverty is not a commitment to a life of destitution; it is a commitment to a communistic practice of property, sharpened by personal austerity. Without a grasp of the three vows at the heart of religious orders, many of the references in conventual writing will be unintelligible. Similarly, many of the conflicts within particular convents will be opaque since they often pivot around conflicting interpretations about how members of the order should live these vows.

It is also helpful for students to understand the theology undergirding the practice of vowed life in religious orders in the Catholic Church. Theologians often ground these three vows in the evangelical counsels found in the New Testament. Unlike the moral commandments, which oblige all Christians, the counsels are recommendations made by Christ to permit his disciples to follow him more intimately. Chastity, for example, is rooted in the commendations of celibacy made by Christ and Saint Paul. The vow of poverty follows the injunction of Christ to sell what one has and give it to the poor and the example of sharing goods in common practiced by the early church in Jerusalem. Vowed obedience is rooted in Christ's obedience to his eternal father and in the epistles' exhortations to obey ecclesiastical governors. Since I teach the texts of nuns in the early modern period, I also take the opportunity to explain why the early Protestant reformers rejected the religious orders as an aberration and a false interpretation of the demands of the gospel.

Another essential characteristic of religious orders is their constitution or rule of life. Approved by the Vatican or the local bishop, the rule specifies the goals and distinctive practices of the order. Many contemporary students, for example, are baffled by the references to the divine office in the writings by early modern nuns. Most convents stipulated the content and horarium of the daily cycle of psalms and hymns (the divine office) to be chanted at specific hours in the convent chapel. The many references to vespers, lauds, and matins suddenly make sense once the legislation on the convent's prayer life is addressed. A convent's constitution reveals its distinctive spirituality:

3 See (See 1983, pp. 105-35). 
its favored devotions, its methods for meditation and sacramental practice, its conception of its mission. The rule also specifies how this particular community practices poverty and exercises authority, two perennial sources of conflict for members of the convent and its external critics. The various rules also indicate the many variations in conventual life. While some convents remained strictly isolated from the world, others directed schools, small clinics, or charitable work for the poor of the region. Jo Ann Kay McNamara's synthetic history of Catholic nuns provides a solid panorama of the many variations and mutations in conventual life over the centuries. ${ }^{4}$

In the early modern period, the convents produced a distinctive literature reflecting the values of the vowed life and of Catholic piety during the storms of the Reformation. The literary genres in which the nuns wrote constitute an obstacle for contemporary students because they diverge so markedly from the essays, novels, and historical works the students are accustomed to read. Background work on genre is often required to make these spiritual texts accessible to students.

Conventual biographies and autobiographies abound during this period, but they are different from the critical biographies written by contemporary historians. Hagiographic in nature, these biographical narratives focus on divine interventions, especially miraculous interventions, in the life of the subject and on the heroic virtues that mark the subject as a saint. One of the era's most popular autobiographies of a nun, the life of Teresa of Avila, illustrates the hagiographical structure of the conventual version of this genre. ${ }^{5}$ Many of these autobiographical texts revolve around the visions received by the author. The supernatural visions of Christ, Mary, the saints, and the angels ground the charismatic authority of the nun who was the recipient. Students often require a semiotic code to interpret the symbols at the center of these visions. The immensely influential vision of the Sacred Heart of Jesus recounted by the Visitation nun Margaret Mary Alacocque, for example, is more comprehensible if the instructor provides background on the widespread devotion to the hearts of Jesus and Mary which marked Catholic piety in the early modern period. ${ }^{6}$

Another common conventual genre in early modernity is the commentary on the Bible and on the particular rule of a given religious community. Again, these commentaries do not follow the standards used by contemporary exegetes who employ the historical-critical approach to the interpretation of Scripture. The nuns use the methods of spiritual exegesis developed earlier by rabbinical, patristic, and medieval authors. If, for example, they are glossing the parting of the Red Sea in the book of Exodus, they show no interest in the historical origin of the text (virtually no nun knew Hebrew; few knew Greek or Latin beyond what was used in their liturgical chants) or in its original author(s) or audience. Rather, they focus on the spiritual truths embedded in the text: how this biblical miracle demonstrates God's liberation of Israel from political oppression, how it anticipates the liberation from sin and death won by Christ, and how it indicates the path a contemporary nun should pursue in seeking liberation from sin and faults. Similarly, the many commentaries of the Rule of Saint Benedict or the Rule of Saint Augustine, the constitutional framework for many of the women's orders during this period, show little interest in the original Latin text, the history of the rule, or the legal issues of the rule's interpretation, which would be left to a male clerical canon lawyer. The nuns concentrate on the spiritual meaning of the text. Numerous conventual commentaries underline the specific moral virtues which particular passages of the rule should inspire in the obedient nun.

Many letters of spiritual direction survive from this era. During the early modern period, growing emphasis was placed on the necessity of having a spiritual director to guide the development of one's spiritual life and to avoid the illusions which arise from too much self-direction. The emphasis

4 See (McNamara 1996).

5 Teresa of Avila's autobiographical Life of Teresa of Jesus (circa 1567) was published and translated into numerous foreign languages immediately after her death in 1582. Along with her other writings, it became even more influential after she was canonized a saint in 1622 and declared a Doctor of the Church by Pope Paul VI in 1970.

6 The visions of the Sacred Heart of Jesus experienced by Marguerite Mary Alacoque (1647-1690) were publicized by her confessor, the Jesuit Claude de la Colombière, and initiated the First Friday devotions, immensely popular in the modern Catholic world to the present day. 
on spiritual direction was tied to the Catholic Church's intensified practice of frequent sacramental confession, a practice which became only more prominent with the Protestant Reformation's rejection of the obligation of auricular confession to a priest. To grasp the purpose of these letters, the students must understand that their focus is to help the addressee advance in the path of salvation and perfection. Detailed counsels on prayer, spiritual reading, and ascetical practices are commonplace in this literature. Many of these letters are also semi-public in nature. Teresa of Avila and Angélique Arnauld at Port-Royal were well aware that their letters were often copied and circulated by the original addressee. Many letters of spiritual counsel by religious superiors were originally addressed to the entire membership of a particular community and quickly circulated beyond their boundaries. Such was the case with the extensive correspondence of Jeanne de Chantal, the co-founder of the Visitation order.

Abbatial conferences constitute another pole of the era's conventual literature. In larger communities, the abbess would meet periodically with members of her community to provide spiritual direction and to clarify issues in their common life. Many of these abbatial conferences are composed of running commentaries on the Rule of Saint Benedict or similar monastic rules. The abbess would provide an authoritative interpretation of the rule, explain its application to her particular convent, and exhort the community to the practice of appropriate moral and theological virtues. Like the letters of spiritual direction, the abbatial conferences often became public documents through the process of transcription, circulation among sister convents, circulation among lay benefactors, and finally print publication. The abbatial conference is one of the key literary genres by which the era's women exercised spiritual authority within a particular convent and throughout the broader church.

To what extent is this conventual literature a species of écriture féminine? ${ }^{7}$ In other words, how does this corpus of texts express the gender-specific spirituality, concerns, rhetoric, and corporality of women? Generalizations easily obscure the individualized voice of each author and the members of women's religious orders share the same concerns as the members of male religious orders in the era of the Reformation. Nonetheless, the analysis of these conventual writings should attend to their recurrent gendered traits. One striking difference from the male monastic literature of the period is what is missing. Since women cannot be ordained in the Catholic Church, the emphasis of much of male ascetical literature on the ministry of priesthood (preaching, administration of sacraments) is absent. Women's exercise of authority through the governance of subjects, spiritual exhortation, and visionary prophecy operates in different channels.

Another gendered difference concerns the imagery employed in the visionary narratives of nuns. Many of these texts stress the status of the nun as the spouse of Christ. The key rituals of conventual life reflect and enact this spousal spirituality. When a candidate for the convent moves from the status of postulant (a brief trial period to test her vocation) to that of novice (a deeper commitment, where she receives the religious habit and assumes a new religious name), the candidate often begins the ceremony by appearing in a bridal dress. The hymns, prayers, and biblical readings (often drawn from the Song of Songs) underscore her betrothal to Christ. When the nun later professes her vows, she begins to wear a wedding ring as a symbol of her spiritual marriage. This marital metaphor suffuses much of the era's conventual literature, most notably in Teresa of Avila's narratives of religious ecstasy. ${ }^{8}$

7 Coined by Hélène Cixous in "The Laugh of the Medusa" (1975), the term écriture féminine originally referred to the need for women to compose writings reflecting and celebrating their gender-specific sexual experience. It was later broadened to refer to the specific literary traits that differentiate women's writing from men's writing.

8 Bernini's statue Ecstasy of Saint Teresa (1647-1652) in the Roman basilica of Santa Maria della Vittoria constitutes the supreme baroque visual representation of the spousal spirituality which dominates much of the era's conventual literature. 


\section{Port-Royal: Cistercian and Jansenist Spirituality}

Situated in the valley of the Chevreuse in the countryside west of Paris, the convent of Port-Royal was founded in $1204 .{ }^{9}$ Originally affiliated with the Benedictine order, the convent later transferred its affiliation to the more austere Cistercian order in 1225. The Rule of Saint Benedict and the Cistercian Carta caritatis remained central references for the spirituality and the written corpus of the convent until its demise in the early eighteenth century. ${ }^{10}$ As F. Ellen Weaver argues, the convent's involvement in the Jansenist movement in the seventeenth century should not obscure the perduring influence of Cistercianism on Port-Royal's spirituality. ${ }^{11}$ Its strict observance of the liturgical office, its rigorist interpretation of the vow of poverty, its cult of Saint Bernard (co-founder of the Cistercians), and even its austere architecture and decoration reflect its longstanding Cistercian influences.

During its first four centuries of existence, Port-Royal enjoyed a good reputation. It obtained numerous privileges from civil and ecclesiastical authorities. The convent could run a boarding school and house laywomen desirous of making a religious retreat. The nuns could elect their own abbess. Like many other French convents caught in the tumult of the Reformation's wars of religion, Port-Royal entered a state of decadence in the sixteenth century. The Bologna Concordat (1516) between Pope Leo X and King François I entitled the French monarch to nominate all the bishops, abbots, and abbesses governing institutions on French soil. The office of abbess at Port-Royal became a political plum, often dispensed to the highest aristocratic bidder. A series of absentee abbesses pillaged the abbey's wealth but neglected its spiritual governance. Cloister collapsed as the nuns visited local taverns and invited the locals to their masked balls during the carnival season. Poverty disappeared as the nuns set up their private apartments, often lavishly decorated. Religious offices were rarely celebrated. The lax convent chaplains were better known from their hunting prowess than for the rare sermons they briskly preached. By the end of the sixteenth century, the convent contained only a dozen nuns, many of them the daughters of the provincial aristocracy without an authentic vocation.

The convent's decline ended in 1602 with the inauguration of Angélique Arnauld as the abbess. Only eleven years old at the time, the new abbess had obtained her post through the corrupt methods typical of the period. The Arnauld family had lobbied King Henri IV to grant them the office of abbess (and, most importantly, the revenues from the convent's properties) as a reward for services rendered to the crown. The Vatican's confirmation of this nomination was obtained by fraudulent documents falsifying the age of the nominee.

In 1608, Mère Angélique underwent a religious conversion and launched a vigorous reform of the convent. The nuns now spent long hours, including night hours, in the convent chapel as they chanted the divine office in simple Gregorian chant. Strict silence was observed as was a strict cloister, separating the nuns from the world, even from the abbess's outraged family members. All personal possessions were abolished in favor of strict communal poverty. The convent's practice of abstinence returned to the primitive Cistercian practice of vegetarianism.

The intellectual culture of the convent rose as the abbess invited eminent theologians such as Benôit de Canfield and Archange de Pembroke to preach in the chapel. ${ }^{12}$ Reading at table included works by Saint Augustine, the desert fathers, and François de Sales. Especially important was the period of the Oratorian ascendancy (1626-1633) when distinguished Oratorian scholars Pierre de

9 For a synoptic history of Port-Royal, see (Weaver 1978).

10 Saint Benedict composed his Rule in approximately 530 to guide the monks in his own monasteries at Subiaco and Mote Cassino. Unlike earlier models of monasticism, which stressed the eremitical life, Benedict's Rule stressed the communal dimension of the monastic life and the key role of the abbot. It quickly became the charter for Western monasticism. Composed by Stephen Harding in 1119, the Charter of Charity stipulated a centralized governance for the order, with all Cistercian monasteries and convents subordinated to the mother monastery of Cîteaux.

11 See (Weaver 1978).

12 An English recusant priest, Benoît de Canfield (1562-1610), was the author of the influential Rule of Perfection, a guide to the spiritual life. A Capuchin priest and mystic, Archange de Pembroke (1567-1632), gained renown as a spiritual theologian and retreat director. 
Bérulle and Charles de Condren gave conferences at the convent. ${ }^{13}$ Bérulle promoted an apophatic theology, stressing divine incomprehensibility, while Condren emphasized annihilation of self as the proper attitude toward the divine will. This imprint of this école française would durably mark the spirituality and writings of the convent.

The Angelican reform had a gendered dimension. The reformed convent re-opened the long-dormant convent school, soon renowned for providing its students with a rigorous theological formation, and once again welcomed laywomen as retreatants. Mère Angélique resumed the tradition of the abbatial conferences; transcribed by the nuns, her commentaries on the Rule of Saint Benedict and others texts received a broad circulation. She also fought to defend the vocational freedom of the women who entered Port-Royal. Much to the chagrin of the aristocracy, she rejected the daughters of the aristocracy who seemed to be forced or unworthy vocations and accepted undowered women who gave evidence of an authentic vocation. Nuns met in chapter to discuss the drafts of a new constitution for the convent and various questions of convent policy. In 1629, King Louis XIII acceded to the abbess's petition that the nuns would elect their abbess for three-year terms rather than having one who received a life-time royal appointment. One of the distinguishing notes of the reformed Port-Royal's spirituality would be its emphasis on the right of women to a theological education, to vocational freedom, and to self-governance.

In the 1630s, Port-Royal became a center for the bourgeoning Jansenist movement. In 1633, the Abbé de Saint-Cyran became the spiritual director of Mère Angélique and a year later the director of the entire convent. ${ }^{14}$ An intimate friend of Cornelius Jansen, bishop of Ypres and professor of theology at Louvain, Saint-Cyran promoted Jansen's radical Augustinian theology. Major themes were radical human depravity, grave human concupiscence, the brokenness of the human will, divine sovereignty, predestination, and the small number of the elect. Saint-Cyran added his own moral rigorism. Given the depth of human sinfulness, Christians should rarely receive Holy Communion; absolution should be granted to penitents only when they evince perfect contrition, that is, sorrow for sins because they have offended God. Saint-Cyran's own written works quickly became a staple of the convent's spiritual reading and the curriculum of the convent school. Jansenist theology and ethics would durably mark the subsequent writings of the Port-Royal nuns.

The dispute over Jansenism intensified in 1640 with the posthumous publication of Jansen's Augustinus. ${ }^{15}$ Jesuit critics charged that, under the cover of Saint Augustine Jansen, Calvinist theology was being promoted. Jansenist critics claimed that it was the Jesuits who were heretical. Their stress on free will and good works was a revival of the Pelagianism Saint Augustine had fought. A series of papal bulls condemned five propositions on grace and free will as heretical and condemned Jansen for having defended these propositions. An opponent of Jansenism, King Louis XIV in 1661 ordered all priests, nuns, and teachers in his realm to sign under oath a formulary assenting to the papal condemnations. During this "crisis of the signature," Antoine Arnauld, the Jansenist movement's leading theologian and the brother of Mère Angélique, offered the ingenious droit/fait distinction to permit the Jansenists to sign the formulary in good conscience. According to this theory, the church had the right to bind its members on matters of droit (faith and morals) since such matters were essential to salvation. But on judgments of fait (empirical fact), the church could not demand such submission since there was always the possibility of error. In the current controversy, the nuns could submit to

13 Pierre de Bérulle (1575-1625) founded the French Oratorians and was a prolific spiritual author, often considered the founder of the "French school" of spirituality, with its characteristic stress on total abandonment to God's will. A theological doctor of the Sorbonne, Charles de Condren (1588-1641) gained renown as a spiritual director and retreat master. He became the general superior of the Oratorians in 1629.

14 Jean du Vergier de Hauranne, abbé de Saint-Cyran (1581-1643) met Cornelius Jansen during his studies at Louvain, became a close personal friend, and staunchly supported Jansen's controversial interpretation of the philosophy of Saint Augustine. Affiliated with the parti dévot, which opposed Cardinal Richelieu's foreign policy as hostile to Catholicism, Saint-Cyran was imprisoned by Richelieu in 1638. His prolific Augustinian writings were widely read, studied, and taught at Port-Royal.

15 For a synthetic history of Jansenism, see (Doyle 2000). 
the condemnation of the five heretical positions (droit) but they must abstain from submitting to the inaccurate and unjust judgment (fait) that Jansen himself had defended such positions.

In June 1661, the nuns gave a reserved signature to the formulary along the lines of the droit/fait distinction. The church and the throne rejected this and subsequent qualified expressions of assent and demanded an unreserved assent to the church's condemnations. The throne proceeded to attack the convent, the center of Jansenist resistance. In 1661, royal delegates closed the convent school, expelled the novices, and forbade the convent to accept new recruits. In 1664, the archbishop of Paris placed the convent under interdict, imposed anti-Jansenist external nuns as superiors, and exiled the convent leaders during the crisis of the signature to house arrest in different foreign convents. In 1665, the recalcitrant nuns were regrouped at Port-Royal and placed under excommunication. Inaugurated by the irenic Pope Clement IX, the Peace of the Church (1669-1679) provided a fragile decade of peace for the convent, now freed from the earlier ecclesiastical sanctions. But the truce was not to last. In 1679, the archbishop of Paris ordered Port-Royal to close its school, send its novices away, and forbade it to receive new vocations. For decades, the aging and diminishing convent suffered a slow death.

Never far from controversy, the convent underwent a new crisis of the signature in 1706 when the nuns offered only a reserved assent to Pope Clement XI's condemnation of laxity in absolving Jansenist penitents. Infuriated by the nun's new gesture of resistance, King Louis XIV exiled the last remaining nuns to house arrest in different convents in 1709. Angered by the nuns' long resistance, he ordered the destruction of the convent buildings in 1710. Much of the literature produced by the convent during this period of persecution centers on a spirituality of resistance, with parallels drawn between the nuns' abandonment and the fate of the prophets and of Jesus on the cross.

As Thomas M. Carr notes, ${ }^{16}$ the enormous extant literature written by the nuns of the reformed Port-Royal has no parallel with any other convent in Europe. A veritable library of letters, conferences, biblical commentaries, monastic commentaries, exhortations, biographies, and autobiographies remains. Certain factors peculiar to Port-Royal explain why the nuns were so committed to the written word. In the early seventeenth century, Port-Royal was considered the model of a reformed convent. Mère Angélique's letters to other nuns, bishops, and priests on the nature of reform were copied and avidly read by outsiders, as were her abbatial conferences. Once a model for emulation, the Jansenizing Port-Royal in the 1630s became an object of suspicion. The convent's clerical allies encouraged its members to write memoirs, biographies, and autobiographies to demonstrate the orthodoxy and holiness of the convent against growing criticism. The Jansenist movement itself quickly became renowned for its network of writers, editors, publishers, and booksellers. Many of the nuns' works, often smuggled across the border, were published by Jansenist communities exiled in the Netherlands. Rather than silencing the nuns, the decades-long persecution of the convent only increased European curiosity about these nuns and a desire to read their own narratives of suffering and resistance.

Another factor is sociological. As William Ritchey Newton notes in his study of the sociology of Port-Royal, ${ }^{17}$ the majority of nuns in 1610 were drawn from the provincial aristocracy but by 1640 the majority arrived from the same noblesse de robe from which Angélique Arnauld and the other Arnauld members of the convent hailed. The noblesse de robe class consisted of the realm's lawyers, judges, and parliamentarians. The daughters of this class of lawyers easily used detailed written texts to make their case against accusations of heresy and for the Augustinian theology of the Jansenists.

\section{Angélique de Saint-Jean Arnauld d'Andilly: Spirituality of Resistance}

The niece of Mère Angélique, Angélique de Saint-Jean Arnauld d'Andilly (1624-1684) spent her entire life at Port-Royal from the moment she entered the convent school at the age of six.

16 See (Carr 2006, pp. 1-25).

17 See (Newton 1999, pp. 59-65). 
A leader of the militant non-signeuse faction of nuns during the successive crises of the signature, she embodies the spirituality of resistance that typified the second generation of the reformed Port-Royal. Elected abbess of Port-Royal (1678-1684), Mère Angélique de Saint-Jean guided the convent through the new persecution which followed the collapse of the Peace of the Church. The most erudite of the convent's abbesses, she astonished visitors by her mastery of Latin and Greek and her grasp of theological controversies. Madame de Sévigné summed up the general opinion of the nun's intellectual culture: "All the languages and all the sciences have been infused into her. She is in short a prodigy." ${ }^{18}$ A prolific writer, she produced an extensive corpus of writings in various genres: biblical commentaries (with a pointed defense of the religious rights of women in the commentary on Esther); commentaries on monastic rules; exhortations (often to resistance to political and ecclesiastical coercion); biographies' autobiography; eulogies; letters (some boldly protesting the mistreatment of the nuns to the pope and the king). Her Discourses on the Rule of Saint Benedict reflects the Oratorian and Jansenist currents of spirituality at Port-Royal. This is especially evident in the treatment of monastic virtues, of which Benedict only provided a brief sketch.

Clearly influenced by the stress of Condren on self-annihilation as the highest goal of the spiritual life, Mère Angélique de Saint-Jean transforms the virtue of humility into a species of self-annihilation. This spiritual annihilation of the Christian is rooted in the mystery of the Incarnation, where Christ annihilates his divine nature in order to appear as human. "He not only lowered himself by clothing himself with the appearance of a servant; he took this very nature upon himself. Since humanity is nothing but a nothingness, God effectively annihilates himself by making himself human. This is our model. If we must judge the humility we should have according to the humility of Jesus Christ, into what type of humility should we enter to pay him homage?" (d'Andilly 1736, p. 407). The Benedictine virtue of humility is thus interpreted through the perspective of the école française, with its characteristic theology of the Incarnation as a species of abandonment of the divine nature and of discipleship as an annihilation of self.

The radical Augustinian theology of the Jansenists permeates this gloss on virtue in Benedict's rule. The treatment of the virtue of obedience is typical. Mère Angélique uses her commentary on Benedictine obedience to defend the controversial Jansenist theory of radical human depravity. According this view, the effects of the fall of human nature are so grave that reason itself can no longer operate properly and no good work can be done outside the impulsion of grace, a sovereign gift of God not dependent on human merit. "In the original state of creation there was a perfect relationship between human reason and will. At the present time, however, this is no longer the case. Reason has become an instrument between the hands of self-will, which uses it in an improper and destructive way by arming itself with the false appearance of reason to find a shadow of justice in injustice itself" (d'Andilly 1736, p. 243). In its unredeemed state, reason has become nothing more than an instrument for the rationalization of vice.

Jansenist theology also appears in the commentary's treatment of the small number of the elect. The tiny minority of the saved stands out from the massa damnata. "Let us recall the great truth taught by Jesus Christ that 'there are many called but there are few elected.' We see the truth of this every day. Only too often it happens that in a great multitude of people there is only one who truly shows the quality of being a child of God and who merits that name by the obedience he or she shows him" (d'Andilly 1736, p. 4). The commentary imports one of the most controversial doctrines of Jansenism, that concerning predestination and election, into a discussion of monastic obedience, although Benedict's original rule, the purported object of the commentary, ignores it.

Many of the abbess's texts develop a spirituality of resistance against the efforts of church and state to coerce the Port-Royal nuns into abandoning their Jansenist convictions. A group of abbatial conferences, Reflections to Prepare the Nuns for Persecution, presents itself as a commentary

18 Madame de Sévigné to Madame de Grignan, 29 November 1679, in (Marie de Rabutin-Chantal 1953-1963, vol. 2, p. 517). 
on the earlier Counsels on the Conduct which the Nuns Should Maintain in the Event of a Change in Government, written by Mère Agnès Arnauld, another aunt of Angélique de Saint-Jean, in 1664 . But Mère Angélique de Saint-Jean alters the tone and doctrine of the original text. Whereas her aunt had counseled prudent material cooperation with foreign superiors imposed on the convent and with the superiors of foreign convents to which the nuns might be exiled (both scenarios actually took place shortly after Mère Agnès wrote her prescient exhortation), Mère Angélique de Saint-Jean exhorts her subjects to militant resistance against the coercion of conscience in the new phase of Port-Royal's persecution. She warns the nuns against efforts to manipulate the vow of obedience. No ecclesiastical or political authority has the right to force anyone to assent to a falsehood. No summons to obedience, including the gendered summons to women to be submissive, can cancel the duty to seek the truth and to suffer for it.

In its spirituality of resistance, Reflections recasts the three theological virtues of faith, hope, and charity, the centerpiece of the Christian moral life. Rather being an intellectual assent to the truths of the gospel, faith emerges as a combative virtue, which plunges the believer into a costly battle with the persecutory world. "Faith teaches us to find glory in disdain, riches in poverty, and life in death. It makes us judge things according to the truth .... Nothing seemed as odious as the death of Jesus Christ. Still, we have been redeemed by it. It will be by the same means, that is, by crosses, persecutions, and afflictions that our salvation will be achieved." ${ }^{19}$ Faith is the commitment to accept persecution gladly as the inevitable fate of the Christian. In the current controversy over the very nature of grace, fidelity rules out compromise and accepts the cross of persecution.

Similarly, charity emerges as the capacity to persevere in lacerating persecutions for the sake of Christ. Martyrdom, even non-sanguinary, is the ordinary fate of the Christian who truly loves God. "It is not excessive to ask Christians that if they do not have the occasion to suffer death for the sake of Jesus Christ, they should at least be disposed to do so. Charity must be strong enough in their hearts to maintain them in this disposition. It is necessary that in rest and peace, as well as in persecution, God sees that they seek only his glory, that they work only for his service, and that they are always ready to sacrifice everything out of love for him." ${ }^{20}$ Recast as a martial virtue, charity places the love of God at the center of a spiritual combat for truth against the forces of persecution. The charity of the nuns should not terminate in a sentimental love of God and neighbor; it must issue in a steely determination to defend the truth of the gospel (as interpreted in the Augustinian theology of Jansen and Saint-Cyran) against the temptation to surrender under political pressure.

Like the virtues, the vices are also recast in this spirituality of resistance under persecution. For Mère Angélique de Saint-Jean, the greatest vice is fear since it demobilizes Christians called to embrace the cross in times of duress but who succumb to their apprehension of the physical and social evils which may befall them if they persist. "There are people who fear evils so strongly that just their fear of them knocks them down before the evils arrive. This feat greatly increases these evils, although we could say that the present evils are minor in and of themselves .... Fear is the greatest of evils because it has not limits. But present evils are always limited and cannot harm us as much as can our apprehension about those that might never occur."21 Just as courageous fidelity to religious truth constitutes the summit of virtue in this spirituality of combat, cowardice, rooted in surrender to fear, constitutes its nadir.

Mère Angélique de Saint-Jean's spirituality of resistance is clearly gendered. She repeatedly warns her subjects of the danger of cultivating the virtues of obedience and modesty, allegedly the particular province of women, when they serve to silence the conscience of the nun. The right of women to protest ecclesiastical and political injustice is tied to the right of women to develop the sophisticated theological culture promoted by the convent and school of Port-Royal. It is the study of the works of

\footnotetext{
(d'Andilly 1737, pp. 205-6).

Ibid., p. 31.

Ibid., pp. 25-26.
} 
Augustine, Bernard of Clairvaux, Teresa of Avila, Jansen, Saint-Cyran, and Antoine Arnauld which permits the nun to grasp the controversies concerning the nature of grace and to take a principled stand on the issue. Critics of the Port-Royal nuns often mocked the Port-Royal nuns as théologiennes because their bold resistance to royal and papal authority sprang from the pursuit of a theological knowledge which most ecclesiastics believed was reserved to ordained males. External resistance is rooted in transgressive knowledge.

\section{Conclusions}

Teaching the texts of Angélique de Saint-Jean indicates the nature of the contextualist challenge in making accessible the conventual canon of the early modern period. These monastic texts remain opaque if the background convent life of the vows and rules and charism of the particular order (in this case, Benedictine and Cistercian) are not elucidated. The abbess's summons to embrace the cross and resist the coercion of conscience during the Jansenist controversy remains enigmatic if students have little knowledge of Jansenism itself and the religious and political quarrels swirling around it. Her discussion of annihilation of self can seem a species of self-hatred to the contemporary student unless the école française's stress on submission to the divine will—which can easily be allied to resistance to the will of errant political and ecclesiastical authorities-is clarified. Rather than being passive, the woman who has undergone this spiritual annihilation of self will find herself in combat with a persecutory world, as Christ did in the self-emptying of the cross. The spiritual empowerment of women operated by the reformed convent of Port-Royal can be illuminated if it is contrasted with the far more limited access to theological culture and to personal spiritual agency found in other convents and convent schools of the period. It can also be paralleled with the contemporary political and economic empowerment of women more familiar to our students.

In my experience, once this contextual work has been done through oral or written commentary, students easily find an existential entry into the writings and person of Angélique de Saint-Jean. Everyone can sympathize with an embattled minority determined to resist the majority for the sake of conscience. Everyone can understand the boldness of the abbess's claims for the right of women to develop a theological culture-and hence to have theological convictions-and to refuse to surrender these beliefs through a gendered command to obey the king and the pope blindly in all things. The specific quarrels over predestination now appear arcane. The spirituality of resistance remains vital.

Conflicts of Interest: The author declares no conflicts of interest.

\section{References}

Carr, Thomas M. 2006. Voix des abbesses du grand siècle: la prédication au féminin à port-royal. Tübingen: Narr, pp. 1-25.

Conley, John J. 2009. Adoration and Annihilation: The Convent Philosophy of Port-Royal. Notre Dame: University of Notre Dame Press.

d'Andilly, Angélique de Saint-Jean Arnauld. 1736. Discours de la Révérende Mère Angéique de S. Jean, Abbesse de P.R. des Champs, sur la Règle de S. Benoît. Paris: Osmont et Delspine, p. 407.

d'Andilly, Angélique de Saint-Jean Arnauld. 1737. Réflexions de la R. Mère Angélique de S. Jean Arnauld, Abbesse de P.R. des Champs, Pour préparer ses soeurs à la persécution. n.p. pp. 205-6.

d'Andilly, Angélique de Saint-Jean Arnauld. 2015. Writings of Resistance. Translated and Edited by John J. Conley. Toronto: Iter Academic Press.

Doyle, William. 2000. Jansenism: Catholic Resistance to Authority from the Reformation to the French Revolution. New York: St. Martin's Press.

Marie de Rabutin-Chantal, Marquise de Sévigné. 1953-1963. Lettres. 3 vols. Edited by Émile Gérard-Gailly. Paris: Gallimard, vol. 2, p. 517.

McNamara, Jo Ann Kay. 1996. Sisters in Arms: Catholic Nuns through Two Millennia. Cambridge: Harvard University Press. 
Newton, William Ritchey. 1999. Sociologie de la communauté de Port-Royal. Paris: Klincksieck, pp. 59-65.

Pascal, Jacqueline. 2003. A Rule for Children and Other Writings. Translated and Edited by John J. Conley. Chicago: University of Chicago Press.

See, Holy. 1983. The Code of Canon Law in English Translation. Translated by Canon Law Society Trust. London: Collins Liturgical Publications, Canons 453-756, pp. 105-35.

Weaver, F. Ellen. 1978. The Evolution of the Reform of Port-Royal: From the Rule of Cîteaux to Jansenism. Paris: Beauchesne. 